\title{
ЭЛЕКТРОННАЯ ТРУДОВАЯ КНИЖКА
}

\section{ELECTRONIC EMPLOYMENT RECORD BOOK}

\section{Ospichev}

Summary: The article discloses the sequence of making a decision on the transition of labor legislation to the possibility of maintaining electronic labor books. The risks of introduction of a new form of personalized accounting of employees by employers are analyzed.

Opinions and positions on the advantages and disadvantages of switching to electronic work books, disadvantages and advantages in their application are monitored. A comparative analysis of the features of maintaining personalized labor records in different countries and their model of maintaining electronic labor books is formed.

Keywords: employee, electronic work book, accounting, personal data, risks of information loss, application, voluntary transition.

\author{
Оспичев Игорь Михайлович \\ К.ю.н., доцент, ФГБОУ ВО «Югорский государственный \\ университет», г. Ханты-Мансийск, \\ iospichev@yandex.ru
}

Аннотация: В статье раскрывается последовательность принятия решения относительно перехода трудового законодательства на возможность ведения электронных трудовых книжек. Анализируются риски внедрения новой формы персонифицированного учета работников со стороны работодателей. Проводится мониторинг мнений и позиций относительно достоинств и недостатков перехода на электронные трудовые книжки, минусов и плюсов в их применении. Формируется сравнительный анализ особенностей ведения персонифицированного учета трудовой деятельности в различных странах и их модели ведения электронных трудовых книжек.

Ключевые слова: работник, электронная трудовая книжка, учет, персональные данные, риски потери информации, заявление, добровольный переход.

трудовая книжка.

Трудовая книжка относится к форме, которую работодатели должны заполнять при приеме работников на работу и при его увольнении. Трудовая книжка является единственным наиболее важным документом в программе страхования занятости.

В России трудовая книжка появилась на заре советской власти. С 15 января 1939 года в СССР были введены трудовые книжки единого образца для рабочих и служащих, всех государственных и кооперативных предприятий и учреждений. С 1940 года был утвержден вкладыш в трудовую книжку. Трудовая книжка является основным документом о трудовой деятельности и трудовом стаже россиянина и выдается в одном экземпляре.

В настоящее время в мировой практике существует два формата записи о занятости: на бумажном носителе и в электронной форме.

В нашей стране до 2018 года применялся бумажный формат ведения сведений о трудовой деятельности работника. Но уже 28 июня 2018 года на заседании правительства РФ было объявлено о поэтапном внедрении в России электронных трудовых книжек. Практический переход на электронные трудовые книжки начался в нашей стране в 2021 году. На сегодняшний день рабочий переход добровольный и выполняется по личному заявлению.

Следует отметить, то Трудовой кодекс Российской

Одним из таких нововведений является электронная ках ведения сведений о трудовой деятельности каждого гражданина должны проводится посредством продуманной политики и через современные механизмы обработки информации. 
Федерации не содержит понятия «электронная трудовая книжка» [1]. Комплексное исследование трудового и пенсионного законодательства показал, что под данным термином понимается информация (сведений) о трудовой деятельности и трудовом стаже работника, которая хранится в информационных базах данных (ресурсах) Пенсионного Фонда РФ.

Согласно правовым актам Пенсионного фонда РФ, электронные трудовые книжки (далее - ЭТК) - это файлы внутреннего информационного обмена, содержащие сведения о трудовой деятельности зарегистрированного лица [3].

По своей сути, ЭТК это официальный документ, в котором содержится вся информация о сотруднике, история его должностных переходов и мест работы, представляющая собой файл, загружаемый в общероссийскую базу персонифицированного учета работодателем.

ЭТК является формой формирования сведений о трудовой деятельности работника, которая идет на смену бумажному формату ее заполнения. С 2021 года все работники должны сделать соответствующий выбор.

Следует отметить, что внедрение ЭТК потребовало внесения изменений в законодательные акты, в том числе о занятости населения, о прокуратуре, о статусе судей, о сельскохозяйственной кооперации, о службе в таможенных органах, об обязательном социальном страховании, о государственной регистрации юридических лиц и индивидуальных предпринимателей, об адвокатской деятельности, о несостоятельности (банкротстве) и др. [2].

Практика применения ЭТК в нашей стране еще не сформировалась, но уже сегодня ведутся активные дискуссии относительно целесообразности и возможностей реализации этой идеи работодателями.

Так, согласно мнению А.Б. Назаренко недостатками ЭТК можно назвать наличие рисковых ситуаций, связанных с утечкой сведений о работнике из-за незаконного использования базы данных работодателя или Пенсионного фонда РФ (далее - ПФР), потенциальные затраты на обновление имеющего программного обеспечения для создания технической возможности передачи сведений о работнике в ПФР и другие [4, С. 213].

А.В. Присекин также говорит о риске потери персональных данных работника ввиду либо сбоя программного обеспечения, либо из-за неправомерного доступа к сведениям о трудовой деятельности работника и иным его персональным данным [5, С. 63].

Кроме того, анализ практики правоприменения ЭТК уже сегодня позволяет выделить следующие недостатки их применения: малые сроки для предоставления отчетности в ПФР, низкий уровень активности работников в части перехода на ЭТК, трудности, связанные с подтверждением стажа трудовой деятельности, отсутствие сведений о наградах и поощрениях работника.

Вместе с тем, плюсами перехода на ЭТК видятся экономия на административных издержках управления, внедрение новых перспективных форм хранения информации и обеспечения ее сохранности, снижение количества трудовых споров по поводу несвоевременной выдачи работнику трудовой книжки, материальная экономия за счет снижения затрат на приобретение или замену трудовой книжки.

Целевая задача ЭТК - новый формат защиты трудовых прав.

Законодатель видит следующие преимущества ЭТК:

- быстрый и удобный доступ к информации о трудовой деятельности;

- дополнительные возможности дистанционного трудоустройства;

- дистанционное оформление пенсий по данным лицевого счета без дополнительного документального подтверждения;

- использование сведений о трудовой деятельности для получения государственных услуг;

- высокий уровень безопасности и сохранности данных.

К плюсам применения ЭТК для работодателя законодатель относит:

- снижение издержек на приобретение, ведение и хранение бумажных трудовых книжек;

- минимизацию ошибочных, неточных и недостоверных сведений о трудовой деятельности;

- новые возможности аналитической обработки данных о трудовой деятельности;

- гарантированное представление Сведений о трудовой деятельности в электронном виде в день увольнения работника (при отказе работника в получении бумажной трудовой книжки).

В первую очередь, электронные трудовые книжки избавят бизнес, отделы кадров компаний от излишних трудозатрат. Это особенно важно для крупных предприятий с большим числом сотрудников.

Также они сведут к минимуму риск потери работниками сведений о своем трудовом стаже, освободят их от обязанности самим заниматься восстановлением данных о том, где и сколько они работали.

В ситуации, когда вследствие реорганизации или 
ликвидации организации работник не может подтвердить свой стаж, уйдут в прошлое.

Ведение учета в электронном виде не ново на мировой арене. К примеру, сегодня такой способ ведения сведений о трудовой деятельности с некоторыми отличиями от российской практики применяется в Испании. В Испании действует электронная система Vida Laboral (трудовая жизнь), в которой фиксируются все приемы и увольнения сотрудников, а также состояние налоговых отчислений. Вся информация автоматически поступает в Министерство труда и Фонд социального страхования.

Так, Отчет о трудовой жизни является официальным документом, который позволяет узнать все периоды, когда каждый человек вносил взносы в социальное обеспечение. Этот документ очень важен при подаче заявления на пенсию или досрочный выход на пенсию, так как в нем можно увидеть общее количество дней, перечисленных в течение всего периода работы.

Наиболее приближен к российскому варианту пример применения электронных трудовых книжек, который планируется внедрить в Белоруссии. Эта страна также нацелена на развитие электронного правительства и информатизацию общества и государственного управления.
Также, в Узбекистане с 1 января 2020 года началось внедрение обязательной регистрации процедуры заключения трудовых договоров и их прекращения на базе «Единой национальной системы труда» («ЕНСТ»). Регистрация трудовых отношений обязательна для всех работодателей независимо от формы собственности и конторской принадлежности, в том числе для отдельных структурных подразделений, частных предприятий и индивидуальных предпринимателей.

На текущий момент определяется перечень сведений, которые будут включаться в информационный обмен для ведения ЭТК.

Таким образом, российский опыт внедрения и применения ЭТК активно применяется и в зарубежных странах. Но некоторые государства (Испания) все же имеют свои особенности ведения учета трудовой деятельности работников.

В целом, внедрение ЭТК направлено на оптимизацию процесса передачи информации в Пенсионный фонд России, консолидацию хранения трудовых книжек работников. Кроме того, переход на ЭТК позволит снизить затраты на ведение кадрового делопроизводства, сократить бумажный документооборот.

ЛИТЕРАТУРА

1. Трудовой кодекс Российской Федерации от 30 декабря 2001 г. № 197-Ф3 / Собрание законодательства Российской Федерации от 7 января 2002 г. № 1 (часть I) ст. 3

2. 0 внесении изменений в некоторые акты Правительства Российской Федерации в связи с принятием Федерального закона «0 внесении изменений в Трудовой кодекс Российской Федерации» в части формирования сведений о трудовой деятельности в электронном виде: постановление Правительства РФ от 10 июля 2020 г. № 1017 / Собрание законодательства Российской Федерации от 27 июля 2020 г. № 30 ст. 4898.

3. об утверждении формы и формата сведений о трудовой деятельности зарегистрированного лица, а также порядка заполнения форм указанных сведений: постановление Правления Пенсионного фонда России от 25 декабря 2019 г. № 730п / Официальный интернет-портал правовой информации» (шww. pravo.gov.ru) 24 января 2020 г.

4. Назаренко А.Б. Практические задачи и риски при переходе на электронные трудовые книжки в РФ / Вестник Академии знаний, 2020 , №37 (2), C. 212-217.

5. Присекин А.В. Некоторые проблемы введения электронной трудовой книжки / Закон и право. 2020. № 1. С. 63-65.

(c) Оспичев Игорь Михайлович (iospichev@yandex.ru).

Журнал «Современная наука: актуальные проблемы теории и практики» 